\title{
Unintended Outcomes of the EHEA and ASEAN: Peripheral Members and Their Façade Conformity
}

\author{
Que Anh Dang
}

\section{Unintended Outcomes of Regional Higher Education Cooperation}

The Bologna Process is a successful European political project aimed at establishing a European higher education model as a synonym for high quality in the competition for normative leadership and providing the basis for new regional higher education projects around the globe, especially in Asia (Enders and Westerheijden 2011; Robertson 2008). The European Higher Education Area (EHEA) - a major outcome of the Bologna Process, and the Association of South-East Asian Nations' (ASEAN) Common Space for Higher Education are widely recognised as outstanding examples of regional cooperation. Each project has its own trajectories of development and model of regional governance, but both have encountered unintended outcomes.

The concept of unintended outcomes can be understood as being unanticipated, unforeseen or different from the actors' intentions or expectations. Unintended outcomes may be linked to positive, neutral or negative consequences of a policy or action. For example, the opportunistic effects of the Bologna Process which created legitimacy for some actors to introduce other changes (e.g. institutional autonomy) with positive impact on the national settings, or adverse effects of the Bologna Process in furthering neoliberal reform of higher education (Dobbins and Leišyte 2014; Musselin 2009; Telegina and Schwengel 2012). Unintended outcomes are not always framed as a failure, but in general as unwelcome or undesired effects for the majority (Burlyuk 2017).

When investigating unintended outcomes, we need to establish the purposes for which a policy or decision was undertaken. Sometimes intentions are declared, other

Q. A. Dang ( $\square)$

German Institute of Global and Area Studies, Hamburg, Germany

e-mail: queanh.dang@giga-hamburg.de

(C) The Author(s) 2018

A. Curaj et al. (eds.), European Higher Education Area: The Impact of Past and Future Policies, https://doi.org/10.1007/978-3-319-77407-7_25 
times they are not explicit and difficult to ascribe. Moreover, objectives and purposes are subject to continuous reassessment, especially in a long-term and multi-layered implementation chain of regional projects. If we look at the Bologna Process, we can see that it was set up to follow a set of stated objectives (i.e. Bologna action lines and benchmarks), making it possible to follow up on the implementation by means of regular stocktaking reports. In most cases, such clearly defined objectives also enable us to identify the unintended outcomes of the process. By contrast, the regional higher education harmonisation process in Southeast Asia was not set up with concrete objectives, rather with a broad goal to "realise the vision of a cohesive and outward-looking ASEAN Community" (ASEAN 2006). We can hardly find any stocktaking reports measuring ASEAN higher education cooperation against pre-set objectives. The process of cooperation is an outcome in itself. The objectives of ASEAN regional higher education activities often become known retrospectively. This paper identifies and analyses some unintended outcomes encountered by the European and Asian regional education projects.

The EHEA was launched in 2010 and currently consists of 48 countries of which 28 countries are currently European Union (EU) members and 20 countries are non-EU members. The majority of the non-EU states are newer members admitted to the Bologna Process between 2005 and 2015. Many of the current 28 EU states, especially the Central and Eastern European countries, joined the Bologna Process during their accession to the EU. The Bologna Process structural reform in these newer EU members has become a significant part of their regional integration after their admission to the EU which, in most cases, took place in 2004 and 2007 (Dakowska and Harmsen 2015). Within the EHEA, the 48 members share a converged degree structure of three cycles of bachelor, master and doctorate, a joint credit system - the European credit transfer and accumulation system (ECTS) and ratification of the Lisbon Recognition Convention for recognition of study periods and qualifications, a cross-border student mobility platform, and a European set of standards and guidelines for quality assurance.

In a similar vein, since the early 1990s, ten ASEAN countries have also been making efforts to harmonise their diverse higher education systems, thus shaping an ASEAN Common Space for higher education. Compared to the Bologna Process, the striking difference is the absence of explicit declarations on establishing such a space and a timetable to achieve the goal. Although higher education has been included in the discussions of the South East Asian Ministers of Education Organisation (SEAMEO) since 1965, ASEAN higher education cooperation really gained importance and was brought to the regional agenda at the 1992 ASEAN Summit that marked the establishment of the ASEAN Free Trade Area (AFTA). The need for greater human resources for the new AFTA was strongly emphasised over previous regional security concerns which were a core rationale for regional cooperation. At the same time, the ending of the Cold War compelled ASEAN to reorient its activities to justify its relevance in the new context (Dang 2017). The ASEAN was also enlarged by admitting new members: Vietnam in 1995, Laos and Myanmar in 1997, and Cambodia in 1999. This reorientation has brought about several significant outcomes, such as the establishment of the ASEAN University 
Network in 1995, the resumption of ASEAN Education Ministers' Meeting in 2005. The process of ASEAN regional higher education harmonisation has so far been built on previous intra-ASEAN cooperation rooted in the decolonisation strategy and the recent adaptation of the Bologna experiences with regards to student mobility and quality assurance.

The EHEA and ASEAN have achieved significant results in their own ways, but they both encountered unintended outcomes that constitute the vulnerability, peripheral status and superficial conformity of newer member countries. In Asia, they are newer members of ASEAN, such as Cambodia, Laos, Myanmar, and Vietnam labelled by the acronym "CLMV". In Europe, they are newer EHEA members and/or newer EU members some of which are lumped together with the tag "CEEC" - Central and Eastern European Countries - and others-with the "post-Soviet" badge. These groups of countries in Asia and Europe are often seen as lagging behind, peripheral or passive (Feuer and Hornidge 2015; Zgaga 2014).

This paper, therefore, raises the questions as to what causes their peripheral status and façade conformity in the regional higher education processes, what other international pressure and influence they encounter that may divert them away from the original regional integration projects. The aim of this paper is not to judge the performance of these countries, rather analyse the underlying reasons that cause their peripheral status and façade conformity that continue to persist to the detriment of regional integration.

\section{Student Mobility and Regional Integration}

\section{The Emergence of Clusters Within the EHEA}

Improving student mobility is "of the utmost importance" in the Bologna Process as stated in the 2001 Communiqué. This key goal has been supported by various pan-European initiatives and high-level strategies. In the beginning of the Bologna Process, mobility between the member countries was promoted because such mobility enables students "to benefit from the richness of the European Higher Education Area including its democratic values, diversity of cultures and languages and the diversity of the higher education systems" (Bologna Process 2001, p. 1). This priority of intra-regional mobility was an essential component of the process of creating a sense of belonging to a European common social and cultural space, thus strengthening and enriching the European citizenship. This goal was also embedded in the European Cultural Convention that was adopted in 1954 to promote cultural exchanges and history and language learning after the two brutal wars in Europe. The parties to the Convention could participate on an equal basis in the cultural cooperation of the Council of Europe, including education with a justification of constructing pan-European unity. The Council of Europe became a consultative member of the Bologna Process in 2001 and the European Cultural Convention was taken in 2003 as one of the main criteria for the eligibility of new member countries 
in the Bologna Process. This criterion also delineates the definition of Europe - a Europe of culture and education manifested in the EHEA. At the 2014 Bologna Process Researchers' Conference, the Armenian Minister of Education and Science, Armen Ashotyan, reminded the participants that "with 19 non-EU higher education systems, the Bologna Process is not only an EU project, but a European project" (cited in Dang 2014). Student mobility is a key tool to realise this region-building project - the EHEA - but in practice it also makes the region segregated.

In a recent study of student mobility patterns between member countries within the EHEA, Shields (2016) uses spatial approach to visualise the student flows that show an emergence of clusters of countries. His main findings support the conclusions that the number of mobile students increased and more countries met the set targets of incoming and outgoing students, but the mobility patterns have, unintendedly, made the EHEA less integrated than when the Bologna Process began. It is the mobility patterns that created clusters of countries. The largest cluster is concentrated around Western European countries, such as the UK, German, and France, which retain a central position; a second cluster centres on Russia and encompasses many post-Soviet states (Armenia, Azerbaijan, Kazakhstan, Ukraine) and other countries in the east of the EHEA; and a third cluster consists of countries towards the south of the EHEA (Greece, Italy, Romania, Turkey). The 2015 EHEA implementation report also confirms that the inflow of students is highly concentrated. That means student mobility is self-contained in clusters which increasingly divide the EHEA into sub-regions rather than an integrated area. This emergence of clusters can be seen as an unintended outcome that challenges the concept of "European Area" and invites critical revision of the EHEA's ultimate goal and model of regional governance.

Looking into student mobility among post-Soviet countries, Heyneman and Skinner (2014) also conclude that the higher education systems of post-Soviet countries - even those within the EHEA (with the exception of the Baltic states) are not entirely connected to those in Western and Central Europe, rather they create a circuit of student mobility distinct from other clusters. Such a connection has not been created by the Bologna toolkit, such as student mobility, nor "the necessary European dimensions in higher education, particularly with regards to curricular development, inter-institutional cooperation" (Bologna Process 1999, p. 4). Although the promotion of European dimensions is a goal and an indicator of the quality of the EHEA, there is no definition of what "necessary European dimensions" are and how they are decided. It is less likely that universities on the periphery of the EHEA, like in the post-Soviet countries, will be able to make changes to pan-European curricula that are not acceded to by the universities of the continent's central powers (Heyneman and Skinner 2014). Conversely, the post-Soviet countries with weaker economic, political and cultural ties to Europe would find it more difficult to implement the EHEA's "European dimensions" in their curricula. Therefore, using the tools such as ECTS guide or Tuning Project to "tune" higher education systems across the EHEA via degree or credit conformity in the name of integration may neither accord with the reality, nor result in recognition of qualifications in practice. 
There were 270.000 Erasmus students in 2012/13 in the entire EHEA (EHEA 2015 , p. 225). Russia alone hosts a total number of 226.431 mobile students internationally (UIS 2017), many of whom are from post-Soviet countries outside of the EHEA. This figure shows a large percentage of internationally mobile students who can be said to study within the EHEA. In other words, the figure can be seen as an indicator of the attractiveness of the EHEA. The sheer size of the Russian higher education system and language compatibility are often considered as two reasons for the student mobility inflows from other post-Soviet countries (Heyneman and Skinner 2014). This paper points to a stronger reason which is embedded in the economic ties between Russia and some of these post-Soviet countries, particularly Armenia, Belarus, Kazakhstan, Kyrgyzstan, that formed the Eurasian Economic Union (EAEU) in 2014. The student mobility patterns (shown in Table 1) provide a possibility for facilitating the free movement of goods, services, capital and labour which have been agreed within this new union. The formation of this concentrated mobility cluster can also be regarded as an unanticipated outcome.

Besides the educational rationale, student mobility has two other main political and economic aims which are to create European-minded citizens committed to the concept of European culture and values and to advance European economic integration via a single market including labour mobility within the EU (Robertson and Keeling 2008). Being an outsider to the EU single market and at the margin of the EHEA, the post-Soviet countries replicate the EU's regionalism strategies to create the Eurasian Economic Union and improve their peripheral status. Economic and educational regionalisation are inextricably intertwined, and student mobility patterns define (and are defined by) the configuration of relationships between countries (Dang 2015). Such economic ties, in turn, reinforce the boundaries between clusters within the EHEA.

\section{ASEAN: From Outward Mobility to Intra-regional Mobility}

Inspired by the experience of the Bologna Process in making student mobility "the basis for establishing the EHEA" (Bologna Process 2003), the ASEAN region, which has a long tradition of sending their students outside the region, has begun to promote student mobility within the region in the last ten years. By contrast, the Bologna Process moved away from its original Eurocentric focus on "making mobility within the EHEA a reality" (Bologna Process 2005) to an "external dimension" (later rephrased as "global dimension") and even introduced a specific target of mobility and a deadline "in 2020, at least $20 \%$ of those graduating in the EHEA should have had a study or training period abroad" (Bologna Process 2009). The common benchmark which only describes outward mobility and counts the total number of graduates in the EHEA has become outdated and even insufficient to measure mobility to and from countries outside the EHEA - an important indicator of the attractiveness of the European higher education system. Therefore, the 
Table 1 Eurasian economic union's students in Russia

\begin{tabular}{l|l|l|l}
\hline Sending countries & Students to Russia & Ratio $(\%)$ & $\begin{array}{l}\text { Total number of mobile } \\
\text { students abroad }\end{array}$ \\
\hline Kazakhstan & 59.295 & 76 & 77.96500 \\
\hline Belarus & 18.804 & 66 & 28.54800 \\
\hline Armenia & 4.446 & 58 & 7.65300 \\
\hline $\begin{array}{l}\text { Kyrgyzstan } \\
\text { (non-EHEA member) }\end{array}$ & 4.430 & 45 & 9.84400 \\
\hline
\end{tabular}

Source UNESCO Institute for Statistics, extracted and compiled by the author in October 2017. (http://uis.unesco.org/en/uis-student-flow\#)

definitions of "balanced mobility", "abroad", and "measurable and realistic mobility targets" became the decisions of each member country (Bologna Process 2012). Generally, the EHEA has changed its strategy which focused almost exclusively on intra-regional mobility to one that promotes extra-regional mobility. The ASEAN region has been doing quite the reverse.

Several ASEAN countries that have traditionally sent students to the West are now diversifying their domestic provision of higher education and enhancing its quality through partnerships with Western universities on their soil. The new educational hubs in Asia, such as Singapore and Malaysia, have not only attracted students from afar but also have become destinations for students within the region (Dang 2016; Lee 2014). As a result, intra-regional student mobility has increased. However, student inflows into these hubs are part of talent development and commercialisation agendas primarily serving national interests, rather than regional integration. Consequently, this kind of intra-mobility makes more visible the differences between ASEAN higher education systems and increases imbalance of mobility, thus causing the peripheral status of some member countries, such as Cambodia, Laos, Myanmar, that have limited national economic resources to send students and limited academic programmes to receive international students.

In order to understand how ASEAN collectively promotes student mobility among its 10 diverse higher education systems, it is important to understand two key regional institutions that have been taking both bottom-up and top-down approaches to realising the ASEAN student mobility agenda. They are the SEAMEO Regional Centre for Higher Education and Development (SEAMEO RIHED) and the ASEAN University Network (AUN) which were established in 1993 and 1995 respectively, and both secretariats have since been based in Bangkok. RIHED is one of 21 specialist centres established by SEAMEO-an inter-governmental organisation of 11 Southeast Asian countries including 10 ASEAN countries and East Timor. AUN is a special association of currently 30 leading universities endorsed by the national Ministry of Education in each ASEAN country. AUN may share some features with the two European organisations, the European University Association (EUA) and the League of European Research Universities (LERU), but AUN is not an equivalent counterpart. AUN was established and sponsored by national education ministries, its participating universities, 
and members of its Board of Trustees must be designated by their respective government. On the one hand, AUN functions as an agent of the governments with a delegated political mandate as part of the catching-up strategy of the ASEAN developmental states. On the other hand, AUN also operates like an independent university association when it comes to academic collaboration including student and staff exchange.

AUN activities concentrate on university partnerships within and outside the ASEAN region for capacity building and on setting regional standards and procedures for quality assurance. Since none of the centrally sponsored and coordinated regional mobility schemes, similar to Erasmus+ or Marie Skłodowska-Curie, exists in ASEAN, AUN facilitates student mobility through university partnerships, particularly the establishment of subject-specific networks. For example, networks of Southeast Asian universities in engineering, public health, business, public policy, international studies. Many AUN universities or their sub-entities (faculties, departments, schools, specialised colleges, member universities) constitute these networks which have as their primary aims to enhance research capacity of academics, share resources and educate master's and Ph.D. students. Enjoying the prestige of its elite member universities, successful cooperation experience and political support from the ASEAN governments, AUN has become not only influential in shaping regional higher education policies but also strategic in forging partnerships with universities, governments, international organisations beyond the ASEAN region, particularly with China, Japan, Republic of Korea, and the EU. Although the works done by AUN have spill-over effects on ASEAN higher education, AUN has mainly been facilitating partnerships amongst elite universities and promoting academic mobility for a small number of students who can compete for scholarships offered by either home or host countries.

On the contrary, SEAMEO RIHED's activities target a broader range of universities in the spirit of community building. The ASEAN International Mobility for Students (AIMS) is a flagship programme coordinated by SEAMEO RIHED. Originated from a pilot project between the three older ASEAN member countries, Malaysia, Indonesia and Thailand, in 2009, AIMS has now become an ASEAN mobility programme, consisting of 68 higher education institutions from six ASEAN countries (Malaysia, Indonesia, Thailand, Vietnam, Brunei, and the Philippines), Japan and Korea (as of November 2016). AIMS provides short-term mobility (one semester of no more than six months) for undergraduate students in ten different study fields which are determined collectively by the participating countries. They include hospitality and tourism, agriculture, language and culture, international business, food science and technology, economics, engineering, environmental management and science, biodiversity, and marine science. There are no plans to expand the range of study fields in the near future, but rather to increase the number of participating higher education institutions in the newly added study fields (environment management, biodiversity, marine science). The sending governments provide funding for their own students, whilst their education ministries nominate the higher education institutions involved in the AIMS programme. Generally, student exchange is based on the reciprocity principle. 
SEAMEO RIHED acts as the overall coordinator which facilitates communication (website, operational handbooks for international officers and students) and chairs the steering committee. The participating institutions decide on the number of students for exchange and on administrative arrangements through bilateral agreements (Sirat et al. 2016). According to SEAMEO RIHED, so far 1800 students have benefited from the AIMS programme. A future plan is to develop massive open online courses (MOOCs) to offer virtual mobility to a larger group.

Both AIMS and AUN mobility programmes operate with the principle of self-sufficiency and solidarity whereby member countries support their own participation and contribute with their academic readiness. Both programmes are of small scale in spite of the fact that ASEAN has a student population of over 15 million and over 7000 higher education institutions (SHARE 2016). There are no pre-set targets, and hence, no benchmarks to measure the level of conformity by each ASEAN member country, simply because "there is no point comparing the hard facts", according to a representative of the ASEAN Secretariat (interview, March 2015). Unlike the pan-European coordinated Erasmus mobility scheme for the entire 37 million students in almost all study fields in the EHEA (2015), SEAMEO RIHED and AUN are organising different schemes with different purposes. "AUN promotes the elite universities in ASEAN, whereas RIHED's activities are more towards inclusiveness" (interview, March 2015). Although there are no discernible mobility clusters in ASEAN as in the EHEA, the intra-ASEAN mobility is faced with different challenges.

First, due to the lack of a central coffer like Erasmus+, the sustainability of intra-ASEAN mobility depends on whether individual member governments are able to provide financial support for student mobility and for the development of international programmes at their universities. Although there is no specific EHEA budget per se, Erasmus+ (previous versions of this funding scheme) is, arguably, the de facto European coffer that sustains the implementation of the EHEA activities as well as the EHEA Implementation Reports.

Second, the Erasmus+is for all EU countries, non-EU programme countries and its partner countries, ${ }^{1}$ which are almost all the EHEA members. The programme does not place a limit on specific higher education institutions in these countries. All ASEAN countries participate in AUN, but with a combination of eligibility criteria, such as quality standards for AUN membership, the size of each higher education system, and the political support and financial commitment of the respective governments. Consequently, Cambodia has two universities, Laos has one, and Myanmar and Vietnam each has three universities in AUN despite the large size of their higher education systems. With regard to SEAMEO RIHED's mobility scheme, at the moment, Cambodia, Laos, and Myanmar do not participate in AIMS largely due to the absence of financial support and academic readiness.

\footnotetext{
${ }^{1}$ Erasmus+ Programme Guide https://ec.europa.eu/programmes/erasmus-plus/programme-guide/ part-a/who-can-participate/eligible-countries_en (accessed 10 November 2017).
} 
Third, even when there are ASEAN regional mobility programmes, the emphasis is still stronger outside the region, especially for the students of AUN elite universities. Some government scholarship schemes of ASEAN countries even encourage their students to go afar by allocating higher grants and rewards for the students who study at higher ranked universities in the West.

In summary, unlike the cultural and linguistic clusters in the EHEA, the ASEAN higher education space is divided by the national economic status of member countries. The high-income and low-middle income countries (Brunei, Singapore, Indonesia, Malaysia, the Philippines, Thailand, and recently Vietnam) are more active in regional projects, whereas the lower income countries (Cambodia, Laos, Myanmar) are focused on policy reform, system expansion and infrastructure development. This divide also constitutes the peripheral status of the newer members.

\section{The Cause of Peripheral Status and Façade Conformity}

\section{The Transformation and Dysfunction of State}

In the early 1990s, higher education reforms took place in the Central and Eastern European countries (CEEC), the post-Soviet countries and newer members of ASEAN in the context of major political and economic transformations in each country (Dakowska and Harmsen 2015; Rany et al. 2012). Generally, these transformations entail the move from authoritarian regimes to democratic ones, and from a closed planned economy to an open market economy. In the Eastern European context, the new governments relinquished their control over universities and liberalised them, both in academic and economic terms. The restoration of university autonomy was the main objective of the reform. The attitude of "returning to Europe" or "catching up with the West" in Eastern Europe was a strong impetus for reforms and it was reflected in their efforts to replace the former educational policies and practices with Western ones as quickly as possible in order to meet the needs of the market economy (Dang 2015; Dobbins 2011; Dobbins and Leišyte 2014; Silova 2011). The CEEC became "laboratories of reform" for experiments on different ideas in reshaping the higher education sector (Dakowska and Harmsen 2015). In many CEEC, higher education reforms took place during the period of their accession to the EU and continued at different stages depending on the national context. The reforms became part of a larger European integration project, in which the Bologna policy tools (degree structures, the common ECTS credit system, the Diploma Supplement, quality assurance) were no longer a reference point, but became a hegemonic influence and even mandatory criteria (Deca 2015). Joining the EU provided a windfall of benefits for many CEEC including funding and access to new knowledge for their stagnating education systems. But the EU's "power of the purse" has spurred actions of domestic actors and exerted considerable leverage in shifting the higher education systems of the CEEC's and 
"Neighbourhood" countries' toward the common EHEA (Batory and Lindstrom 2011). Furthermore, for those newer members of the EHEA, the Bologna agreed action lines, benchmarks and timetables were presented as non-negotiable and conformity was expected. In sum, unintended outcomes in these cases were the so-called "coercive voluntary" participation and "façade conformity" to the Bologna rules and standards.

In the CLMV countries, higher education reforms also took place during their accession to the ASEAN, there were neither requirements for structural reforms of higher education, nor financial incentives (and pressure) from the central coffer as in the EU. On the contrary, the governments (or universities) had to spend more on joining regional programmes. Their peripheral status in the ASEAN regional process is caused by the limited capacity of their higher education systems. Different wars and isolation periods have, to varying degrees, destroyed higher education in these countries. In Myanmar, a violent and erratic military regime strategically dismantled the nation's higher education system until 2011. As of 2013, only $11 \%$ of the nation's young people had any kind of higher education. And in most cases, the quality of that education is suspect, since learning materials are often dated or unavailable after 50 years of destruction, isolation, and neglect (Anderson 2016; Kamibeppu and Chao 2017). The November 2015 election in Myanmar gave its mandate to a National League for Democracy which is committed to reengineering the higher education system. Similarly, Cambodia was estimated to have lost $75 \%$ of its higher education lecturers and nearly all (96\%) of its students through genocide, persecution and escape from the Khmer Rouge regime between 1975 and 1979 (Rany et al. 2012). Subsequently, the development of Cambodian higher education has faced many problems in providing educational services because of political instability and civil war until 1998. Hun Sen assumed the Prime Minister's post in 1998 and he sought to rebuild higher education infrastructure almost from scratch with very scarce resources. This disastrous legacy still haunts Cambodia's higher education system today, explaining its many challenges. With the rapid expansion of higher education in the last decade, governance remains a major challenge. There is no single authority overseeing all higher education affairs although the Ministry of Education, Youth and Sports (MoEYS) and the Ministry of Labour and Vocational training have the most higher education institutions under their wings. However, in practice, the Cambodian higher education institutions and their regional branches were supervised by 14 government ministries and agencies and the regulatory mechanism is built around "an overdose of outdated, incoherent, patchy and reactive policy documents" (Cheong and Ghanty 2016, p. 31). In brief, in these two cases, the dysfunction of the nation-state can arguably be seen as causing the low capacity for regional integration, thus the peripheral status of the higher education system.

In Laos and Vietnam, higher education reforms have been influenced by the international partners and financial providers. Since the mid-1980s there has been a heavy external investment in the education sector in Laos, and the external development partners wielded considerable influence on development policy including higher education (Noonan et al. 2013). For example, the Asian 
Development Bank (ADB) has provided grant and loan assistance of some USD 70 million in 2009 and 2016 to improve Laos' higher education systems (ADB 2016). Similarly, Vietnam has also taken three tranches of a loan of USD 150.000 million provided by the World Bank for implementing three major higher education reforms (Dang 2009). Consequently, higher education reforms in both countries have been redefining the role of the nation-state and reframing the role of the market in higher education governance.

\section{The Rise of Private Higher Education}

A common trend in all CEEC, former Soviet countries, as well as in CLMV countries is the rapid expansion of private higher education providers in the past two decades (Dang and Nguyen 2014). There are many types of private higher education provision, but the three most common types in these countries are local private institutions, foreign branch campuses, and joint programmes between local public universities and foreign universities. Most of them were established in the 1990s and the number increased rapidly. For example, the number of Polish higher education institutions increased from 115 in 1996 to 258 in 2002 (Simonová and Antonowicz 2006) and 338 in 2010-2011 (Dakowska 2015). Unlike other sectors, privatisation in higher education in most CEEC has not resulted from foreign investment, rather it appeared to be a domestic phenomenon. In the CEEC, the share of students attending private higher education institutions has increased and accounted for roughly $30 \%$ of the total enrolments in Estonia, Poland and Romania, and lesser scale in Hungary, Russia, Slovenia (Dakowska 2015). However, tuition fees have been introduced in for-profit programmes at a number of public higher education institutions. Therefore, the proportion of fee-paying students may exceed $50 \%$ of the total student population (ibid). The initial reforms in most CEEC in the 1990s were to liberalise the higher education sector from authoritarian regimes, thus resulting in its partial privatisation. In the 2000s, the reforms were justified by the Europeanisation agenda and accelerated by the Bologna tools for competition (e.g. quality assurance) and by the European funds. Consequently, the demarcation between privatisation/marketisation and Europeanisation became blurred. This may be seen as an unintended outcome or at least an undeclared objective of the Bologna Process.

The newer ASEAN members also experienced an explosion of private higher education institutions. In Cambodia the number of higher education institutions grew from only 8 public institutions in 1997 to 105 in 2014, of which 66 were private, as a result of the soaring demand for higher education for the labour market after Cambodia became a member of ASEAN in 2009 and the WTO in 2004 (Rany et al. 2012; Un and Sok 2014). Private institutions serve more than $60 \%$ of students (Feuer and Hornidge 2015). In Vietnam, the number of higher education institutions increased from 153 in 2000 to 421 in 2013, of which private institutions increased from less than 10 in 1999-2000 to around 100 in 2012-2013, enrolling some 
300.000 students (Dang and Nguyen 2014). In both Cambodia and Vietnam, the lack of human capital and the shortage of resources have led to the emphasis on quantitative expansion over qualitative improvement. The new private providers focus on teaching and neglect research and social public service. They offer courses which require the least investment in infrastructure and serve vocational demands, such as business, marketing, accounting, English language, information technology. Many of these institutions employ underpaid lecturers from public institutions who seek extra income.

In terms of quality, there are various issues: the joint programmes and foreign campuses are of better quality, whereas many local private providers and the unclear legislation about private higher education are sources of concerns. For example, they may offer a degree to students who can pay, but the entry requirement and student responsibility to perform may be under-emphasised. In Ukraine, for instance, the State Attestations Commission withdrew licenses from 116 educational programme, branches, affiliates in 2006 alone, just one year after the country joined the Bologna Process (Osipian 2009). In the EHEA and ASEAN, quality assurance and credit transferability are two sides of the same coin because credit transferability is a de facto measure of quality, since such transfers rely on an agreement between two institutions that the credits in question represent a certain quality/quantity of educational attainment or learning outcomes. One major unintended outcome is that the local private institutions' reputation and the quality of their programmes, on the whole, cause complications for the regional efforts of the Bologna Process and ASEAN to make degrees and credits transferable between countries.

\section{Corruption in Higher Education}

Corruption is reported in many public services, but the increase of corruption in the education sector is serious in many newer members of the EHEA and ASEAN. Since national laws differ and legality/illegality are not universal, corruption in higher education is time- and space-specific and may be found in private as well as public institutions (Osipian 2009). Education is a special public good, its professional standards include more than just material goods, hence, education corruption is defined as "the abuse of authority for personal and material gain" (Heyneman 2004, p. 638). According to several studies of corruption in post-Soviet countries, phenomena such as payment for grades, bribery to gain entrance to university, or corruption in institutional accreditation and licensing have become so commonplace as to threaten the reputation of entire systems (Heyneman and Skinner 2014; Osipian 2009, 2012). More dangerously, the Russian students' attitude becomes more favourable towards corruption as they pass through their university years (Denisova-Schmidt et al. 2016) because they socialise with learning various cheating techniques and become more confident in corrupt practices. They may transfer this attitude to their professional lives, thus hampering economic and social 
development. The consequences of corruption in the higher education sector include higher cost of hiring, lower graduate salaries, reduced economic returns expected to higher education investments. Furthermore, at the systemic level, efficiency reduces where corruption occurs. For example, instead of increasing the competition within the university, bribery limits competition and reduces quality (Heyneman et al. 2008).

One of the subtle but serious forms of corruption in the former communist higher education systems is associated with the creation of branches of national prestigious public universities in various provinces within the same countries. This phenomenon was pervasive in the 2000s in many post-Soviet countries and also in Vietnam, and it is different from the foreign university branch campuses which were set up in other national jurisdictions. The branches were to maximise revenue for the public universities in the form of tuition fees and other informal payments, but the quality of programmes offered at those branches was poor. These branches created room for corruption because the degrees conferred by the branches were not different from those conferred in the central (original) institutions. Moving away from a planned economy, the discourse "decentralisation" was strongly promoted in these former communist countries. However, in practice, decentralisation in the case of university branching has also led to an increase in corruption because delegation of power to lower levels created room for abusing discretion (Heyneman 2007; Heyneman and Skinner 2014; Osipian 2012).

Although some improvements have been made, an unintended consequence for regional cooperation in the EHEA and ASEAN has been that the reputation of these higher education systems derailed the transferability of credits and degrees with other countries in the region they have joined. It is difficult to imagine why a country or a university with a high reputation would allow its degrees to be made equivalent to those of a university or higher education system with a reputation for corruption. Moreover, as mentioned earlier, education is a special public good, whose function is to teach students standards of personal conduct and professional ethics. If the education system is corrupt, one can expect future citizens to be corrupt as well.

\section{Influx of International Influences}

The newer members of the EHEA and ASEAN are also influenced by other international partners with different geo-economic and geo-political visions. As part of the "Belt and Road Initiative", China established a new cooperation platform with 16 Central and Eastern European countries (CEEC) in 2012. The CEEC group includes 11 EU countries: Bulgaria, Croatia, the Czech Republic, Estonia, Hungary, Latvia, Lithuania, Poland, Romania, Slovakia and Slovenia; and five non-EU countries from the Balkans: Albania, Bosnia and Herzegovina, "the former Yugoslav Republic of Macedonia", Montenegro, and Serbia. All these CEEC countries were placed on the eastern side of the "Iron Curtain" dividing Europe. 
The financial crisis of 2008 made the CEEC turn to China in search of investment, financial cooperation and new trade agreements. The new grouping has convened an annual "China-CEEC Summit" since 2012 (www.china-ceec.org). Besides a vast amount of credit for infrastructure, such as airports, high-speed railways, roads, the Chinese government planned to provide 5000 scholarships for students of the CEEC to study in China and an investment fund of USD 3 billion to expand cooperation in science, technology, innovation, environmental protection (Musabelliu 2017). A new student mobility pattern is in sight as the economic ties with China become increasingly stronger.

In a similar vein, ASEAN has also been experiencing an influx of international geopolitical changes in the region. While China is active in the CEEC, the EU is taking the relations with ASEAN to the next level with "a partnership with a strategic purpose" (EC 2015). Higher education is a priority in the partnership. A four-year EU-funded project "Support to Higher Education in the ASEAN region" (SHARE) was launched in 2015 to share the Bologna Process experience and build a stronger higher education area with 400 scholarships for student mobility within the ASEAN region. The project also gives special support to the CLMV group (Cambodia, Laos, Myanmar, Vietnam) to narrow the development gap in ASEAN.

Moreover, the relationship between ASEAN and the United States resumed in 2009 under the Obama Administration. The ASEAN Economic Community has become the fourth largest goods and export market for the United States (USAID 2016). Alongside the traditional development donors such as Japan and the European Union, the United States and China are becoming increasingly influential in ASEAN. Since 2014, the CLMV group has been implementing the five-year workforce development programme "Connecting the Mekong through Education and Training" sponsored by the U.S. Agency for International Development (USAID COMET). The project supports universities and vocational schools to adapt their curriculum and teaching approach, specifically in the Science, Technology, Engineering, Mathematics, Accounting and Tourism (STEM-AT) sectors, to better meet private sector demands and prepare graduates of the lower Mekong countries to enter the increasingly competitive labour market of the ASEAN Economic Community. Besides the cooperation with the multinational technology companies, such as Cisco, Google, Intel and Microsoft, for internships, COMET also provides short-term mobility to universities and colleges in the United States. By 2019, USAID COMET will help 20 higher education institutions equip 120,000 students with the workplace skills, and set up professional networks, such as "Women in science and technology" in the region (USAID 2016).

Although Western Europe and North America are still the favourite study destination of ASEAN students, a new trend of "studying closer to home" has emerged. Not only the generous scholarships provided by China, Japan and Korea, but also closer economic relationships between these countries and the ASEAN region have influenced student mobility. In the recent year, these three Northeast Asian countries have set targets to increase numbers of international students and the majority of students are from Asia (ASEAN included) as shown in Table 2. 
Table 2 Asian student mobility ratio in China, Japan, Republic of Korea (2005-2011)

\begin{tabular}{l|l|l|l|l}
\hline Countries & $\begin{array}{l}\text { Incoming } \\
\text { international } \\
\text { students in } \\
2005\end{array}$ & $\begin{array}{l}\text { Incoming } \\
\text { international } \\
\text { students in } \\
2011\end{array}$ & $\begin{array}{l}\text { \% of international } \\
\text { students from Asian } \\
\text { countries in 2005 }\end{array}$ & $\begin{array}{l}\text { \% of international } \\
\text { students from Asian } \\
\text { countries in 2011 (\%) }\end{array}$ \\
\hline China & 141,000 & 293,000 & n.a & 87 \\
\hline Japan & 126,000 & 152,000 & $94 \%$ & 93 \\
\hline $\begin{array}{l}\text { Republic } \\
\text { of Korea }\end{array}$ & 16,000 & 63,000 & $92 \%$ & 94 \\
\hline
\end{tabular}

Source Adapted from (ADBI/OECD/ILO 2014, p. 17)

Compared to the modest scope of the two ASEAN mobility programmes mentioned earlier (e.g. AIMS supports 1800 mobile students in 8 years), the total number of ASEAN students studying in China, Japan and Korea is significantly larger. Over 60.000 students from Vietnam, Indonesia and Thailand study in China as shown in Fig. 1.

The obvious challenge for intra-ASEAN mobility is to improve quality and diversify the study offers in English. A representative of the ASEAN Secretariat shares the thought that "[...] we want to see the gravity shifted back to the ASEAN countries, but this is a very difficult undertaking" (interview, March 2015).

ASEAN Students in China, Japan, Repulic of Korea $(2015,2017)$

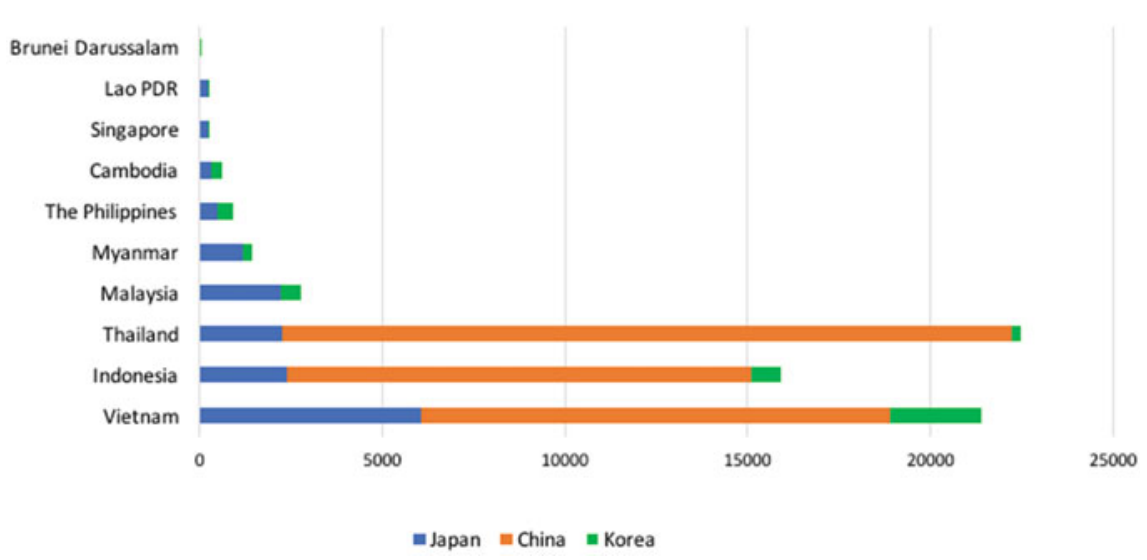

Fig. 1 ASEAN students in China, Japan, the Republic of Korea (2015, 2017). Source UNESCO Institute for Statistics, extracted and compiled by the author in October 2017, for the data of ASEAN students in Japan and Republic of Korea. (http://uis.unesco.org/en/uis-student-flow\#). Project Atlas, extracted by the author in October 2017, for the data of students from Indonesia and Thailand (in 2015), and Vietnam (in 2013) in China. Data of students from other ASEAN countries in China are not available or insignificant. https://www.iie.org/Research-and-Insights/ Project-Atlas/Explore-Data/China 


\section{Implications for Future Regional Cooperation}

This paper has sought to analyse some unintended outcomes and their causes of the regional higher education projects in Europe and Southeast Asia. Although both the EHEA and ASEAN aimed at creating regional common space of harmonised higher education systems, the implementation outcomes have shown the emergence and existence of clusters of countries within these spaces. Generally, in the EHEA students tended to move from the East to the West (or from newer EU member states to the older ones) and/or from smaller higher education systems to larger systems, whereas in the ASEAN region the tendency has been from larger systems (Indonesia, Thailand, Vietnam) to smaller but more advanced systems (Singapore, Malaysia) where English is more widely spoken.

In both regions, student mobility has been used as a tool to construct regional higher education space, but mobility has also been a factor that divides such supposedly integrated space into segregated clusters. Apart from the usual cultural and linguistic rationales, this paper pointed out that political and especially economic relationships between countries within the EHEA and ASEAN are a decisive cause shaping student mobility patterns and clusters of countries, such as the Eurasian Economic Area and the lower Mekong basin countries. Hence, in devising future policies, student mobility cannot only be seen as an end in itself, it is vital to revisit both the political goals and academic projects (pedagogical nature) of mobility beyond the idea of benchmarking against the common standards across members.

The paper also underlined the kind of façade conformity of newer members that continues to persist to the detriment of regional integration. One cause of such façade conformity is that the Bologna Process puts "structure before content" (Papatsiba 2006) and newer members have little (or no) choice to negotiate the systemic structural higher education reforms and the pre-set benchmarks. Many components of such structural reforms and policy tools, including the use of financial leverage, have led to a number of unintended outcomes at domestic and regional levels. The Bologna policy tools were designed for regional integration and shared with Asia, but integration may not be achieved by declaring the name of a higher education area for what in fact is not. As the paper demonstrated, the rise of poor private higher education, declining quality and corruption in both public and private institutions of "the dishonest few can destroy the reputation of the honest majority" (Bergan 2011, p. 66). Thus, the recognition of qualifications across higher education systems will remain unrealistic, and regional cooperation on equal terms will only be a benign version of regional talks between ministerial officials.

Although exclusion of member countries is not yet a practice in the EHEA and ASEAN, the peripheral status - in essence, a form of exclusion - has become a key feature of the clusters consisting of newer members of the regional projects, be it higher education or economic integration projects. In the EHEA, the peripheral status or low achievement of newer members has been made even more visible by the implementation monitoring reports. This paper suggests that such a peripheral status will be improved if some of the underlying causes, particularly the issues of 
corruption and academic malpractice, are tackled effectively and in different ways for specific national, institutional and departmental contexts. Beyond the "name and shame" tool, such as the implementation report, more support and assistance mechanisms should be introduced. For example, regional expert groups should be set up, relevant guidelines should be initiated, and more research into the issues should be encouraged, including the function of nation-states, economic and cultural practices and consequences of educational corruption and malpractice, governance models at macro, meso and micro levels.

In the changing global geo-economic context, even when European integration projects provide a strong reference frame and financial incentives for processes of national structural changes, various international pressure and domestic contexts still matter a great deal. Based on the analysis of several new sub-regional economic projects, such as the $16+1$ grouping between 16 CEEC and China, interventions of the World Bank, Asia Development Bank and international donors in some ASEAN higher education systems, the paper further argued that influx of multiple, overlapping and even conflicting international influences also causes disintegration, façade conformity and complex reconfigurations of the higher education systems in the CEEC, post-Soviet and CLMV countries. Such international influences make the EHEA and ASEAN regional spaces of higher education porous.

In conclusion, the Bologna Process and EHEA carry with them a multiple and changing European identity, whereas ASEAN common space for higher education is a nascent project, hence, in the process of constructing a regional identity. The EHEA's ability to continue to leverage this European identity and use it in the pursuit of advancing social, political, cultural and educational objectives will impact its sustainability and normative leadership. ASEAN's deliberations should focus on academic integration activities rather than manufacturing political consent if members are to reap the benefits of regional higher education space.

\section{References}

ADB. (2016). ADB to Help Lao PDR improve quality of higher education and TVET. Asian Development Bank News Release.

Anderson, K. D. (2016). Myanmar in transition: Higher Ed a likely priority for the NLD-led government. Retrieved from https://wenr.wes.org/2016/03/myanmar-in-transition-higher-ed-alikely-priority-for-the-nld-led-government.

ASEAN. (2006). Joint statement from the 1st ASEAN education ministers meeting and 41 st SEAMEO Council Conference.

Batory, A., \& Lindstrom, N. (2011). The power of the purse: Supranational entrepreneurship, financial incentives, and european higher education policy. Governance, 24(2), 311-329.

Bergan, S. (2011). Not by bread alone. Strasbourg: Council of Europe Publishing.

Bologna Process. (1999). The Bologna Declaration.

Bologna Process. (2001). Towards the European higher education area. Prague Communiqué.

Bologna Process. (2003). Realising the European Higher Education Area. Berlin Communiqué.

Bologna Process. (2005). The European higher education area-Achieving the goals. Bergen Communiqué. 
Bologna Process. (2009). The Bologna Process 2020-The European Higher Education Area in the new decade. Leuven/Louvain-La-Neuve Communiqué.

Bologna Process. (2012). Mobility for Better Learning-Mobility strategy 2020 for the European Higher Education Area (EHEA).

Burlyuk, O. (2017). The "Oops!” of EU engagement Abroad: Analyzing unintended consequences of EU external action. Journal of Common Market Studies, 55(5), 1009-1025.

Cheong, K., \& Ghanty, S. (2016). Higher education, transnational education and the evolution of the Cambodian education system. In C. Hill \& R. M. Fernandez-Chung (Eds.), Higher Education in the Asian Century: The European legacy and the future of transnational education in the ASEAN region (pp. 21-40). Routledge: Abingdon.

Dakowska, D. (2015). Between competition imperative and Europeanisation: The case of higher education reform in Poland. Higher Education, 69, 129-141.

Dakowska, D., \& Harmsen, R. (2015). Laboratories of reform? The Europeanization and internationalization of higher education in central and Eastern Europe. European Journal of Higher Education, 5(1), 4-17.

Dang, Q. A. (2009). Recent higher education reforms in Vietnam: The role of the world bank EPOKE working papers on University Reform.

Dang, Q. A. (2014). New momentum and energy behind Bologna. University World News, 19-21. Retrieved from http://www.universityworldnews.com/article.php?tory=20141204142250509.

Dang, Q. A. (2015). Trajectories of lifelong learning reforms in Latvia. In Lifelong learning and the new agenda (pp. 16-18).

Dang, Q. A. (2016). Academic mobility for enhancing Asia-Europe connectivity: Why and How?, in Asia-Europe Connectivity: Recent Development and Future Outlook, pp. 277-298. Asia-Europe Foundation, Singapore.

Dang, Q. A. (2017). Regionalising higher education for repositioning Southeast Asia. Oxford Review of Education, 43(4), 417-432.

Dang, Q. A., \& Nguyen, D. C. (2014). Governance in Vietnamese higher education. In Leadership and governance in higher education (Vol. 4).

Deca, L. (2015). International norms in the reform of Romanian higher education: A discursive analysis. European Journal of Higher Education, 5(1), 34-48.

Denisova-Schmidt, E., Huber, M., \& Leontyeva, E. (2016). On the development of students' attitudes towards corruption and cheating in Russian Universities. European Journal of Higher Education, 467.

Dobbins, M. (2011). Explaining different pathways in higher education policy in Romania and the Czech Republic. Comparative Education, 47(2), 223-245.

Dobbins, M., \& Leišyte, L. (2014). Analysing the transformation of higher education governance in Bulgaria and Lithuania. Public Management Review, 16(7), 987-1010.

EC Joint Communication to the European Parliament and the Council. (2015). The EU and ASEAN: A partnership with strategic purpose. Adopted by the European Commission and the High Representative of the Union for Foreign Affairs and Security Policy on 22 June 2015.

EHEA. (2015). The European higher education Area in 2015. Bologna Process Implementation Report.

Enders, J., \& Westerheijden, D. F. (2011). The Bologna Process: From the national to the regional to the global, and back. In R. King, S. Marginson, \& N. Rajani (Eds.), Handbook on globalization and higher education (pp. 469-484). Northampton: Edward Elgar.

Feuer, H. N., \& Hornidge, A.-K. (2015). Higher education cooperation in ASEAN: Building towards integration or manufacturing consent? Comparative Education, 51(3), 327-352.

Heyneman, S. P. (2004). Education and corruption. International Journal of Educational Development, 24(6), 637-648.

Heyneman, S. P. (2007). Three universities in Georgia, Kazakhstan and Kyrgyzstan: The struggle against corruption and for social cohesion. Prospects, 37(3), 305-318.

Heyneman, S. P., \& Skinner, B. T. (2014). The Bologna Process in the countries of the former Soviet Union: an outsider's perspective. Journal of the European Higher Education Area, 1, $55-71$. 
Heyneman, S. P., Anderson, K. H., \& Nuraliyeva, N. (2008). The cost of corruption in higher education. Comparative Education Review, 52(1), 1-25.

Kamibeppu, T., \& Chao, R. (2017). Higher education and Myanmar's economic and democratic development. International Higher Education, 88, 19-20.

Lee, J. (2014). Education hubs and talent development: Policymaking and implementation challenges. Higher Education, 68, 807-823.

Musabelliu, M. (2017). China's belt and road initiative extension to Central and Eastern European Countries-Sixteen nations, five summits, many challenges. Croatia International Relations Review, 23(78), 57-76.

Musselin, C. (2009). The side effects of the Bologna Process on national institutional settings: The case of France. In A. Amaral, G. Neave, C. Musselin, \& P. Maassen (Eds.), European integration and the governance of higher education and research (pp. 181-205). Dordrecht: Springer.

Noonan, R., Phommalangsy, P., \& Phetsiriseng, I. (2013). Lao PDR: The great transformation. In L. PeSymaco (Ed.), Education in South-East Asia (Vol. 1, pp. 115-136). Oxford: Continuum.

Osipian, A. L. (2009). Corruption hierarchies in higher education in the former Soviet Bloc. International Journal of Educational Development, 29(3), 321-330.

Osipian, A. L. (2012). Education corruption, reform, and growth: Case of Post-Soviet Russia. Journal of Eurasian Studies, 3(1), 20-29.

Papatsiba, V. (2006). Making higher education more European through student mobility? Revisiting EU initiatives in the context of the Bologna process, comparative education, 42(1), 93-111.

Rany, S., Zain, A. N. M., \& Jamil, H. (2012). Cambodia's higher education development in historical perspectives (1863-2012). International Journal of Learning and Development, 2(2), 224-241.

Robertson, S. L. (2008). The Bologna process goes global: A model, market, mobility, brain power or state building strategy? (pp. 1-17). Invitational paper to ANPED's Annual Conference, October 2008, Brazil.

Robertson, S. L., \& Keeling, R. (2008). Stirring the lions: Strategy and tactics in global higher education. Globalisation, Societies and Education, 6(3), 221-240.

SHARE. (2016). Towards greater harmonisation of higher education in Asean. Policy Brief 1. Jakarta, Indonesia.

Shields, R. (2016). Reconsidering regionalisation in global higher education: Student mobility spaces of the European higher education area. Compare: A Journal of Comparative and International Education, 46(1), 5-23.

Silova, I. (2011). Higher education reforms and global geopolitics: Shifting cores and peripheries in Russia, the Baltics, and Central Asia. Russian Analytical Digest, 97, 9-12.

Simonová, N., \& Antonowicz, D. (2006). Czech and polish higher education. Bureaucracy to Market Competition, 42(3), 517-536.

Sirat, M., Azman, N., \& Bakar, A. A. (2016). Harmonization of higher education in Southeast Asia Regionalism: Politics first, and then education. In S. L. Robertson, K. Olds, R. Dale, \& Q. A. Dang (Eds.), Global regionalisms and higher education projects, processes, politics. Cheltenham, UK. Northampton, MA, USA: Edward Elgar.

Telegina, G., \& Schwengel, H. (2012). The Bologna process: Perspectives and implications for the Russian university. European Journal of Education, 41(1), 37-49.

UIS. (2017). Global flow of tertiary-level students. Exacted by the author in October 2017. Retrieved from http://www.uis.unesco.org/Education/Pages/international-student-flow-viz.aspx.

Un, L., \& Sok, S. (2014). Higher education governance in Cambodia. Leadership and governance in higher education. Raabe Academic Publishers, 4, 71-94.

USAID. (2016). Connecting the Mekong through education and training. USAID Bangkok.

Zgaga, P. (2014). The role of higher education centres in research and policy: A case from a European periphery. Studies in Higher Education, 39(8), 1393-1404. 
Open Access This chapter is licensed under the terms of the Creative Commons Attribution 4.0 International License (http://creativecommons.org/licenses/by/4.0/), which permits use, sharing, adaptation, distribution and reproduction in any medium or format, as long as you give appropriate credit to the original author(s) and the source, provide a link to the Creative Commons license and indicate if changes were made.

The images or other third party material in this chapter are included in the chapter's Creative Commons license, unless indicated otherwise in a credit line to the material. If material is not included in the chapter's Creative Commons license and your intended use is not permitted by statutory regulation or exceeds the permitted use, you will need to obtain permission directly from the copyright holder. 